\title{
Forging Ahead without an Affirmative Action Policy: Female Politicians in Sierra Leone's Post-War Electoral Process
}

\author{
Hussaina J. Abdullah
}

\begin{abstract}
In contemporary post-conflict Sierra Leone, women have managed to secure 13.5 per cent of seats in parliament - without affirmative action in place, thanks to women's groups' and coalitions' mobilisation and activism. While the political resistance to Sierra Leone having a quota was high, the women's movement has succeeded in forcing the political parties and the government to recognise that it is no longer politically viable to sidestep women's rights, should they wish to capitalise on women's voting power. As women's organisations, in particular the 50/50 group, continue the struggle to introduce a quota, the challenge for Sierra Leonean women is how to ensure that the quota project is not hijacked by the male-dominated political establishment. To this aim, this article examines the ongoing efforts to politically consciencise women parliamentarians, society and political parties.
\end{abstract}

\begin{abstract}
1 Introduction
Post-war Sierra Leone has had four elections, two each at the local and national levels since the end of the country's brutal civil war in 2002. It is now preparing for its third cycle of elections for the period 2012-17. These elections are significant in that they mark the return to normality and political stability in the country, after many years of being subject to humanitarian backing. ${ }^{1}$ The re-introduction of the elections also paves the way to the reinstitution of a system of local governance after three decades of being frozen. The elections have also opened up opportunities for women to step up their demands for affirmative action and participation in public life. The first post-war election, the Presidential and Parliamentary election held on 14 May 2002, witnessed an increase in the number of female parliamentarians from its 1996 figure of 5, to 18 . At the local level, there were 107 female contestants in the 2004 local election and 54 were elected as councillors. This figure increased to 225 and 86 contestants and elected councillors, respectively, in the 2008 election.
\end{abstract}

This article examines the struggles of women's organisations and coalitions to seize the political moment of the formation of a post-conflict Sierra Leone to press the government to recognise women's political rights through the introduction of affirmative action. The political trajectory of Sierra Leone in engaging with the question of a quota for women has not however, followed patterns observed in other sub-Saharan African countries. Rwanda (an exceptional case) has the highest percentage of women in parliament worldwide (56.3 per cent), while six African countries $^{2}$ can boast of having over 30 per cent female representation in their national Parliaments, and another seven ${ }^{3}$ of having over 20 per cent female parliamentarians (InterParliamentary Union 2010). In Burundi, Mozambique, Rwanda and Uganda among others, the post-conflict time opened up opportunities for introducing affirmative action. However, in some other sub-Saharan contexts, such as Sierra Leone, the demand for an affirmative action policy was vehemently opposed by the state, a position that was maintained throughout the Constitution Review process in 
2007, despite the fact that there are legislative initiatives supporting its implementation. This resistance notwithstanding, female politicians with the assistance of women NGOs have increased their participation and representation in national and local political arenas.

This introduction to this article is followed by a section which discusses women's participation in politics from the early independence period, specifically 1957, when suffrage was extended to all women, and up to 2008, when the second local government election was conducted. The article then focuses on women's activism and their engagement with the state and other actors in their advocacy for the adoption of an affirmative action policy. The final section presents an analysis of the way in which the state has engaged with women's demands for the implementation of an affirmative action policy.

\section{Women's participation in Sierra Leonean politics pre-2000}

Sierra Leonean women's participation in the country's modern political structures began in 1938 with the election of Constance CummingsJohn to the Freetown Municipal Council (Denzer 1978: 444). This feat was repeated at a higher level in 1954 when Mabel Dove became the first woman in West Africa to be elected to the legislature (Government of Sierra Leone: GoSL 2004). Although suffrage was extended to all women in 1957, it did not result in a groundswell of female contestants in the election that year. Only four women contested the election: two from the colony (Freetown) and two from the provinces. Mrs Cummings-John became the first black African woman to govern a capital city by winning the 1961 Mayoral election. This trend was short-lived as local governance was abolished in 1972 and administrators were appointed to run the affairs of the various councils in the country.

Since Paramount Chiefs ${ }^{4}$ were allowed to participate in the electoral process, Ella KobloGulama of Kaiyamba Chiefdom, Moyamba District, became the only female parliamentarian and first minister of state in West Africa (Steady 2006: 37). It was this government that led the country to independence on 27 April 1961. She continued being the lone female in national politics until 1967, when the Sierra Leone Peoples Party (SLPP) lost the country's second postindependent election.
Sierra Leone's post-colonial political history is blotted with coups, counter-coups, one-party dictatorship and finally, a civil war. The All Peoples Congress (APG) party's success in the 1967 general election signaled the beginning of the end of multiparty politics and women's participation in elective politics. Women's participation in parliament under the APG was through appointment, especially as the 1978 oneparty constitution gave the President the executive power to appoint 10 persons to Parliament. Women's token representation continued under the military (1992-6).

Even though tokenism continued with the introduction of multiparty politics in 1996, Mrs Jeredine Williams of the Coalition for Progress Party broke the glass ceiling in Sierra Leonean politics by vying for the presidency. Although she withdrew her candidature before the polls, her bravery must have inspired Zainab Bangura, whose running mate was Deborah Salam, a woman who contested the presidency in the 2002 election. Another political party, the United National People's Party had a female running mate. The 1996-2002 parliamentary sessions had only five women out of 80 parliamentarians and two female cabinet ministers and deputy ministers each out of 25 and 20, respectively. Although women's activism before and during the 1996 Presidential and parliamentary elections did not translate into any meaningful representation in politics as they were once again out-manoeuvred by the male-dominated political machinery, they were at least credited for their role in the struggle for the reintroduction of multiparty politics (Steady 2006: 53).

\section{Women's political agency in the post-civil war era, 2002 onwards}

The post-2000 era is strikingly different from earlier periods in Sierra Leone's political history, because of the end of the civil war and the emergence of Fifty-Fifty (50/50), a non-partisan women's campaigning organisation committed to creating gender balance in politics and decisionmaking processes. The end of a civil war represents a political moment laden with opportunities for change and reform of existing political configuration; proportional representation instead of the usual constituency/first-past-the-post system was used in the electoral process. The proportional party list system and 50/50's training, advocacy and 
lobbying political parties to put women higher on their party lists by demanding the use of the zipper system, i.e. alternating women and men on party lists, all contributed to the high performance in the elections.

The number of female contestants in the 2002 presidential and parliamentary elections rose from 65 in 1996 to 156, and elected parliamentarians from 5 to 18 (two women Paramount Chiefs) or 14.5 per cent of members of parliament. Unfortunately, this increase was not reflected in ministerial appointments, as women accounted for only three cabinet ministerial positions out of 21 and three deputy positions out of 10. At the parliamentary level, the deputy speaker was a woman and six of the 23 Chairpersons of the Parliamentary Committees were women (Agriculture, Food Security, Health and Sanitation, Education, Science and Technology, Public Accounts, Information and Communication and HIV/AIDS) (Lahai 2009).

There was considerable difference in the electoral landscape in 2007. No woman vied for the Presidency, while three contested for the Vice-Presidential tickets of their political parties, with only one being successful. The number of female contestants dropped to 64 and elected parliamentarians to 16 (13.5 per cent) of the current parliamentary cycle of 2007-12. In parliament, there is no female Paramount Chief or Deputy Speaker and the number of Chairpersons of Parliamentary Committees dropped from six to five (Health and Sanitation, Marine Resources, Human Rights, Gender and Children's Affairs and HIV/AIDS) out of a total of 30. Female representation dropped in the 2007 election with the reintroduction of the first-pastthe-post system, as political parties refused to heed the women's movement's demand for a gender-sensitive (cancellation of nomination fees, nomination of women in safe seats and the adoption of a gender quota) nomination process (in Sierra Leonean parlance: the award of political party symbol). The internal dynamics of the nomination process is biased against women, as there is no female representation in the selection committee. In addition, female candidates complained of outright discrimination and harassment in the award of symbols and the lack of an ombudsman to seek recourse. Three women were appointed ministers in 2007 but there is only one woman in the cabinet as at May 2010. However, the three female deputy ministers still hold on to their various portfolios.

Women's re-engagement in the elective process at the local level, started with restoration of local governance in 2004. During this electoral cycle 2004-8, 54 of the 107 women who contested the election won, constituting 13.7 per cent of elected councillors. At the Mayoral/Chairpersons and Deputy levels, women accounted for 5.3 per cent and 10.5 per cent of elected officials in the 19 District/Town Councils, respectively. Three female councillors won the Parliamentary elections in 2007. The number of female contestants for councillorship increased by over 100 per cent from its 2004 figure of 107 to $221^{5}$ in the 2008 election; candidates for the position of Mayor increased from one to four. A total of 86 women representing 17 per cent of councillors won the 2008 election. Unfortunately, no woman won the Chairperson/Mayoral election. Three (15.7 per cent) of the 19 Deputy Chairpersons/ Mayors are women. In relation to Paramount Chieftaincy, Paramount Chiefs are the traditional head of a chiefdom of 5-15 locales. Sierra Leone has 149 chiefdoms, and 12 PCs representing the 12 Districts of the former Protectorate are elected to parliament by the elders of the districts. There are 11 female Paramount Chiefs (PGs) (7.4. per cent) out of 149 PGs and one woman Court chairperson. Presently, there are four female candidates for PC elections in 39 Chiefdoms. It is worth pointing out that all of these women are from the Southern and Eastern Provinces (except Kono and Kailahun Districts) of the country, where women are allowed to contest for the Paramount Chieftaincy title. The two women aspirants from Kono and Kailahun Districts were disqualified, primarily because of their gender! (Lahai 2009).

Through the efforts of women activists and NGOs, the number of contestants and elected councillors in the 2008 local government elections rose significantly. Moreover, the phenomenon of women running as independent candidates, which is a rarity in African politics, became part and parcel of the electoral process. Unlike 2004, when there was only one female independent candidate, in 2008 the number of independent female candidates rose to 29 (12.8 per cent) of female contestants because of the material and technical support provided by women's groups to female contestants who were 
sidelined by their political parties. The Women Solidarity Support Group (WSSG), a coalition with membership from Grassroots Empowerment for Self Reliance (GEMS), Campaign for Good Governance (CGG), 50/50 and the Search for Common Ground, with the aim of supporting Sierra Leonean Women in their quest for equality and human rights, organised a two-day symposium and honouring event - 'Honouring Women's Initiative', in January 2008 to recognise women community leaders, parliamentarians, councillors, activists and NGO professionals. One of the outcomes from this event was a call to increase women's participation in the 2008 local election. As a result, the Women's Solidarity Fund (WSF) was established to pay the nomination fees of female candidates and support their campaigns. The group mobilised resources from corporate sponsors, and organised fund-raising activities such as a walkathon and dinner-dance, to enhance women's chances at the polls. Apart from the conventional support of training and capacity building to strengthen women candidacy, money was given directly to candidates to print posters and T-shirts and entertain their supporters. After the election, a post-election workshop for contestants was organised by CGG to assess the outcome of the election and develop a plan of action for future elections.

Further, the WSF coalition ensured the revitalisation of the Network of Women Councillors and the Sierra Leone Female Parliamentary Caucus whose aims included increasing women's participation in decisionmaking positions as well as lobbying for the revision of discriminatory laws against women.

It is through the concerted efforts of the agency of women in political office and the women's organisations and coalitions that opportunities were created and sustained for women to enter politics, even when they were denied through the conventional political pathways of power, namely, political parties, and an electoral system that secures minimal representation through affirmative action.

\section{The struggle for a gender quota in post-war} Sierra Leone

The organisation of a platform to demand the introduction of a gender quota in post-war Sierra Leone is credited to the Fifty-Fifty (50/50) group which was founded in 2000. The group's primary objective is to promote and increase women's participation in politics and create a gender balance at all levels of public life. Its activities include recruiting, training and supporting female political aspirants. The group has trained over 3,000 women for both local and general elections. In cooperation with other women's groups, 50/50 provided funding and support to female politicians to stand as independent candidates during the last local government elections. Under the auspices of the Women's Forum, the umbrella organisation of the Sierra Leone women's movement, 50/50 and the National Organisation of Women (NOW) formed a coalition to draft a Women's Manifesto to use as an advocacy and campaigning tool in their demand for a minimum of 30 per cent female representation in politics and public institutions. As part of this process, the 50/50 group and NOW once again brought women's groups together in 2004 to demand that government allocate 30 per cent of local council seats to female contestants and to include more women in the Taskforce ${ }^{6}$ (especially as the Taskforce's sole female member was a representative of an international organisation). The demands were presented to the then Vice-President, the Minister of Local Government and Community Development and members of the local government Taskforce that was deliberating the draft Local Government Act (Majeks-Walker 2009).

Although the government was sympathetic to the women's demands, their request for 30 per cent reserved seats for women was rejected. However, three members of the coalition, Mrs Abattor Thomas, then president of 50/50, Mrs Iyesha Josiah, the president of Sierra Leone Association of NGOs (SLANGO) and the Honourable Dr Bernadette Lahai, MP of the SLPP, the then ruling party, were invited to become part of the Taskforce. It has been argued that the presence of these women in the Taskforce was 'pivotal in engendering the Local Government Act 2004, particularly with regards the composition of the Ward Development Committee and the Local Government Service Commission' (Lahai 2009). The 2004 Local Government Act stipulates that 50 per cent of members of the Ward Development Committees should be women. Although it is a non-paying position, it is a very important structure, as it is at this level that the development agendas of the community and local government are developed. The five 
member Local Government Commission is made up of three women and two men.

Just before the 2007 presidential and parliamentary elections, the 50/50 group and its coalition partners, in collaboration with ENCISS (an NGO called Enhancing the Interaction and Interface between Civil Society and the State to Improve Poor People's Lives), revised the Women's Manifesto, and ran a 'Women's Election Watch Plus - 9 Days to Go Campaign'. The campaign was to ensure the safety and security of female candidates and a fair and peaceful conduct of the presidential and parliamentary elections. The Coalition once again presented a Position Paper on the issue of a 30 per cent quota - this time to the Constitutional Review Committee (CRC 2008). Even though the women argued their case very well, noting that the TRC had recommended that the reviewed constitution should include a minimum 30 per cent quota to engender the country's political landscape and buttressed their argument further by using various regional and international instruments, such as the African Charter on Human and Peoples' Rights (ACHPR) and on the Rights of Women, the United Nations Convention on the Elimination of all Forms of Discrimination Against Women (CEDAW) and the International Convention on Civil and Political Rights, the CRC rejected their demand outright. The GRC rejected the women's demand for a 30 per cent quota because it felt it was 'elitist' and did not have support outside of Freetown, the capital city. As a result of this claim, the WSSG decided that as part of the 2010 International Women's Day celebration, it would launch a campaign to be followed up with a monthly dialogue forum on the quota issue (WSSG 2010a). In launching this campaign, the WSSG wants to mobilise national support for its advocacy project on gender quotas by getting women at all levels of the society involved in the sensitisation exercise. The group intends to intensify the campaign by facilitating a dialogue between women and various stakeholders in the country, especially in the Provinces.

The first Dialogue Forum on 'Women's Chieftaincy Rights and the 30 per cent Quota' was held in Kono District, Eastern Province on 16 March 2010. Kono was chosen as the site for the launch to sensitise locals and the entire nation on the plight of women seeking political office. Elizabeth Kumba Simbiwa Sorgboh Torto was denied the right to stand for the PC election in Kono District. The Sierra Leone Chieftaincy Act states that an individual is qualified to stand as a candidate, 'if he was born in wedlock to a rightful claimant in a recognised ruling house in the Chiefdom'. The Act further notes that 'where tradition so specifies, he or she has direct paternal or maternal lineage to a rightful claimant in a recognised ruling house, whether born outside wedlock or not' (GoSL 2009). Mme Torto was qualified on both counts, as she was the daughter of a PG which put her in good standing to vie for the chieftaincy election in her district. Thus, the Kono Forum was an opportunity to strengthen the solidarity among women working towards greater political participation in Sierra Leone and with female politicians.

The WSSG wants to use the ongoing review process of the recommendations made by the CRC to ensure that the issue of the women's demand for a minimum 30 per cent gender quota is included in the amendments to the constitution. The group feels that it is the right time to engage with the issue as it will be difficult to do so after the constitutional amendments have been accepted by parliament. Furthermore, the group wants the new constitution with a gender quota for women to be ready before the country's third post-war electoral cycle in 2012.

Since the Kono Forum, the WSSG has launched a monthly dialogue series in Freetown to discuss issues pertaining to the 30 per cent quota. The first dialogue in April focused on the Presidential Apology to Women (see below), in May, it was on the 30 per cent quota the government has promised women and the June dialogue will be on the review of the CRC's recommendations. The monthly dialogue series will be replicated in the other three administrative regions in the very near future to get more women involved in the project.

The primary objective of the WSSG is to advocate and campaign for the protection of the rights of women through the judiciary, legislature and in the wider community. This is done through a combination of advocacy campaigns, rallies/demonstrations, test-case litigations and by creating places where women 
can meet and network according to the terms of their own agenda (WSSG 2010a). In 2008, it mobilised support for women candidates fielding the local council elections through capacity building and resource mobilisation, then in March 2009, it launched a campaign to advocate for sexual and gender-based violence victims and to raise awareness about the procedures involved in reporting rape cases. The group is currently actively involved in the issue of the 2010 Paramount Chieftaincy elections in which two women were denied the right to stand for election. Some WSSG's achievements include:

- Pressurising the government to set up a Commission of Enquiry to look into rape cases that took place during the political fracas between the two main parties, the APC and the SLPP

- A pending Supreme Court case on the rights of women to stand for Paramount Chieftaincy

- A standing network to coordinate activists' response to issues concerning women (WSSG 2010b).

Women's groups have also argued that the legislative foundations for establishing a quota already exist in the current system in Sierra Leone. For example, the government had earlier outlined its vision for women's political empowerment in the National policy for the Advancement of Women adopted in 2000 by Parliament. The general objective of the policy is to improve women's status by eliminating discrimination against women in the society and enhancing their capabilities as agents of economic, social and political development. In particular, the policy aims to facilitate the appointment of women to executive and decision-making positions in the civil service and in government. In this regard, the policy notes that:

- Government shall increase women's participation in decision-making through the adoption of [an] affirmative action-quota system and by setting specific goals, timetables, targets and numbers.

- Government shall increase the number of women in leadership positions in the public and private sectors by 40 per cent by the year 2005 with a view of achieving parity.

- Government shall ensure participatory democracy in all institutions as participatory democracy is a necessary mechanism for equal treatment and participation for all members of society.

In addition, the Truth and Reconciliation Commission (TRC) established in 2000 by an act of parliament as part of the government's reconstruction process made

recommendations on how to enhance women's political participation and access to power in post-war Sierra Leone. The Commission stated that:

Simply calling for the opening up of the political space is not sufficient. If Sierra Leone is serious about giving a meaningful voice to women in representative politics, then more serious efforts have to be made to this end. (GoSL 2004)

Based on this assertion, the Commission went on to make some recommendations to the government on how to increase women's political visibility:

- Those political parties are required to ensure that 30 percent of their candidates for public elections are women. This includes national elections, local government and district council elections. Legislation should be enacted to make this a legal requirement. The National Electoral Commission should be required to enforce this minimum representation

- Government and Parliament work towards achieving 50/50 gender parity in representative politics (national and local), in cabinet and political appointment within the next 10 years

- That the government work towards achieving a representation of at least 30 per cent women in cabinet and other political posts.

Government should also work toward an incremental increase, achieving 50/50 parity in cabinet and political posts within the next 10 years

- Recommends leadership training programmes for young women in both the Provinces and Freetown to ensure that there is a new generation of women with sufficient skills to participate in public life.

(GoSL 2004)

Women's groups have argued that these two initiatives have a legal basis as they have parliamentary recognition and as such, they are 
easily implementable if the government wants to do so. They have argued further that the gender quota proposal can be accommodated within the current constitutional framework as both Sections 27.4(g) and 74 permit such legislative changes (King 2009). Women have thus anchored their demand for a gender quota from a legal perspective to show that the Constitution Review Committee's (CRC) rebuttal of their demand has no legal grounding.

\section{State and political party response to women's demand for affirmative action}

Unlike most post-war societies that adopted new constitutions as part of their reconstruction process, Sierra Leone is still governed by the old constitution written in 1991. To bring it in line with other post-conflict societies, the then government launched a constitution review process on 11 January 2007. Unfortunately, the demand by women for the inclusion of a gender quota was rejected. In their rebuttal of the women's demand, the GRC stated that:

We see no reason why we should recommend a quota system in our multi-party constitution. As the 50/50 Group stated in one of their documents presented to us: 'Democracy is representation of the people by the people for the people.' In this country that

representation in Parliament is selected by all registered voters in a secret ballot and no distinction is made between men and women. (Constitutional Review Commission 2008: 16)

After their well thought out refusal of women's demand, the CRG noted the following:

All the Conventions demand affirmative action in favour of women. We, the Commission, support this and strongly recommend greater educational opportunities for women so as to prepare and enhance them for a major participation in politics and public offices. In this regard, special provision should be made for the empowerment of women in the hinterland of the provinces, in education, business and other development. As Dr Fama Joka Bangura, a former distinguished woman diplomat, remarked in a recent article, '... at the moment, $30 \%$ representation will be limited to a very small proportion of the number of women in the country'.

(Constitutional Review Commission 2008: 16)
The Chairman of the GRG notes that the quota issue was not raised in any of their consultations and that the CRC only confronted it during the report writing stage. He stated further that the nine of the women's ten-point demands were accepted by the CRC. He believes that gender quota is unconstitutional in a multiparty democracy, and would like to know how the beneficiaries will be selected, the constituencies they will represent and the manifesto they will articulate. 'Gender quota is the responsibility of political parties since they determine the nomination process of candidates to be selected for election' (interview with Dr Peter Tucker, 23 May 2010).

Although the GRG is an independent Commission, its decision is of great significance because its Chairman was then Law Reform Commissioner and an old SLPP stalwart. As such, its recommendation is analysed as part of the government's response to the gender quota project. If the SLPP had won the 2007 election, Sierra Leonean women would have had a Herculean task ahead to battle out the CRC recommendation review process. Maybe the winning of the election by the populist APC is a sign that there are good things ahead for Sierra Leonean women. Although the APG government did not move beyond the SLPP's record of ministerial and deputy ministerial appointments, it brought the gender quota issue at the centre of the country's political and economic discussions by stating in the PRSP 11 document, An Agenda for Change, that his government intends to 'introduce a temporary affirmative action plan that stipulates a 30 per cent quota in elective and appointed positions as recommended by the Beijing Platform for Action and the Truth and Reconciliation Commission' (GoSL 2008: 95). At the 2010 International Women's Day celebration, which was postponed from 8 March to 27 March, the President Ernest Bai-Koroma fulfilled one of the TRC's recommendations that the President should apologise to Sierra Leonean women for the atrocities they endured during the war. The President did not stop at the apology but went a step further to assure Sierra Leonean women that his government will adopt an affirmative action policy to increase their representation in public life:

As Head of State I apologise for the wrongs wrought on women, as Commander-in-Chief I ask for 
forgiveness for the armed forces, as Fountain of Honour and Justice I pledge this country's commitment to honour, protect, and defend the rights and aspirations of the women of this country. As a Sierra Leonean man, I urge all men of this nation to stand by women to defeat these long-standing injustices suffered by more than half our population... we will adhere to women's demands for a 30 per cent quota in Parliament and other significant areas of governance; our judiciary is today headed by women and it is our belief that this singular fact will make the interpretation and implementation of justice reflective of the deep commitment of women to justice, equal rights and equal opportunities.

The President's promise to adopt a gender quota to increase women's political participation has galvanised Sierra Leonean women into action, as they want to maximise the benefits that will accrue from affirmative action policy. In doing so, they have been confronted with some

challenging questions from women voters across the country asking, 'why they should support women, when the women are not accessible once they get into power' (discussion with Barbara Bangura, Monday 31 May).

It is heartening to know that the SLPP under whose tenure women's demand for a 30 per cent quota at the local and national political level was rejected, now has a draft gender policy that if adopted, will increase women's participation and representation at all levels of the party's structures and in public life. We do not know if this turnaround is genuine or just a political gimmick to jostle with the APC for women's vote. Whatever their motive is, it means the voice of Sierra Leonean women on the quota project is now at the centre of the country's national political dialogue. However, women activists are wary of the motives of both political parties because of their poor gender equality record and fear that their stance is a vote-buying strategy in the run-up to the 2012 elections, because women constitute 52 per cent of the country's population. As such with women's new found voice and strength, no political party can afford to ignore them.

\section{Concluding comments}

Unlike other post-conflict sub-Saharan countries, Sierra Leone did not adopt affirmative action to enhance women's political representation in the 2002 parliament. Nonetheless, the 14.5 per cent women's representation in the parliament 2002 is a percentage that can be considered considerably higher than that reached in many other countries that had instituted a quota. The ability to mobilise support for women gaining political office in 2002 is attributed to an organised campaign involving several women's organisations but also thanks to a system of proportional representation. The removal of the proportional representation system in the most recent elections of 2007 contributed to the drop of women gaining seats in parliament to 13.5 per cent. In that sense, the electoral system adopted by a country plays just as a decisive role in enhancing representation as affirmative action measures.

The coalition of women parliamentarians, women NGOs and women activists in sustaining concerted efforts to support women's access to political office has provided opportunities for political empowerment, where conventional pathways such as political parties have been inhibitive. The technical, financial and legislative support provided through women's activist groups has been critical in providing a sustained form of support for women candidates, without which it would have been very difficult for women to overcome the inequities in the political system which undermine ascension to political office. Women's coalitions however, are becoming increasingly conscious of the need to become particularly discerning in the kind of women they support to political office, and the agendas they espouse.

The fact that women's coalitions and organisations have contributed to the increased presence of women in political office in the lower house and in the local councils has increased their political weight, and hence bargaining power, vis-à-vis the government and political parties. This has also been achieved by seizing every political opportunity possible to step up their campaign for an official commitment to political parity. They have contested the allegations of the demand for a quota being elitist by carrying out a large scale nationwide sensitisation campaign that includes holding dialogues and forums with different stakeholders, including women.

Despite government rejection of their demand for an affirmative action policy to increase women's political representation, women's 
organising efforts for the adoption of a gender quota policy are growing stronger by the day. Women activists have demanded that the gender quota be implemented either through the use of the zipper system of representation in politics, i.e. one man-one woman on party lists or reserved seats for women.

Sierra Leonean women have continued to organise and mobilise around the gender quota project and intervene in political discrimination cases to ensure that the issue of political parity/quota is at the centre of the review of the recommendations of the CRC. They have organised various forums to sensitise the public on the issue, acted as a pressure group and watchdog to advance the discourse on equitable political representation and frontally engage political parties, the state and other stakeholders in this process. The assurance given by the President and

\section{Notes}

* I am grateful to Barbara Bangura, Marcella Macauley and Joy Samake for their efforts in facilitating my research.

1 The Lome Peace Agreement ending the war was signed in 1999 but the end of hostilities was only declared in 2002.

2 South Africa (44.5 per cent), Mozambique (39.2 per cent), Angola (38.6 per cent), Uganda (31.5 per cent), Burundi (31.4 per cent) and Tanzania (30.7 per cent).

3 Namibia (26.9 per cent), Lesotho (24.2 per cent), Seychelles (23.5 per cent), Mauritania

\section{References}

Constitutional Review Commission (2008) Final Report of the Commission to Review the Constitution of Sierra Leone, 1991

Denzer, L. (1987) 'Women in Freetown Politics, 1914-1916: A Preliminary Study', Africa 57.4: $439-56$

Government of Sierra Leone (GoSL) (2009) Chieftaincy Act, Freetown: Government Printer

Government of Sierra Leone (GoSL) (2008) An Agenda for Change: PRSP11, Freetown: Government Printer

Government of Sierra Leone (GoSL) (2004) Truth and Reconciliation Report, www.sierraleone.org/other-Conflict/TRGVolume3b.pdf (accessed 25 May 2010)

Inter-Parliamentary Union (2010) Women in National Parliaments: World Classification, the SLPP's formulation of a gender policy reflecting the adoption of a gender quota shows that women's struggles have not been in vain.

Thus, the discourse and demand for a gender quota in post-war Sierra Leone, which began with the formation of the 50/50 group in 2000, is now a national political project embraced by the state and the two main political parties. The question then to ask is, if Sierra Leonean women will be able to make good use of the forthcoming opportunity of the elections of 2012 to push through an emancipatory agenda for gender equality in the society - capitalising on their ability to influence women's voting power. The challenge will be to arrive at a form of affirmative action that withstands the government and political parties' desire to hijack the process and subsume women's needs and interests under the national political project.

(22. 1 per cent) Ethiopia (21.9 per cent) and Malawi (20.8 per cent).

4 In Sierra Leone, Paramount Chiefs (PC) are members of Parliament but are elected by the Chiefdom councils in their districts. There are 12 districts in the country.

5 This figure does not include candidates who stood for Mayoral elections.

6 The Taskforce was set up to review responses from the national consultation on the nature and form of local governance and to draft a Bill to reflect the responses from the field.

www.ipu.org/wmn-e/classif.htm (accessed 13 May 2010)

King, J. (2009) 'Quotas Within Sierra Leone's Legal Framework', paper presented at the Workshop on Advocacy Intervention for the Legislation of 30 Per Cent Quota Representation for Women in Political Leadership in Sierra Leone: Challenges, Opportunities, Strategies, organised by the Campaign for Good Governance, 16-17 December

Lahai, B. (2009) 'Trends in Women's Political Participation in Sierra Leone', paper presented at the Workshop on Advocacy Intervention for the Legislation of 30 Per cent Quota Representation for Women in Political Leadership in Sierra Leone: Challenges, Opportunities, Strategies, organised by the 
Campaign for Good Governance, 16-17 December

Majeks-Walker, N. (2009) 'Background Paper on the 30 per cent Quota Advocacy in Sierra Leone', paper presented at the Workshop on Advocacy Intervention for Legislation of 30 Per cent Quota Representation for Women in Political Leadership in Sierra Leone: Challenges, Opportunities and Strategies, organised by the Campaign for Good
Governance, 16-17 December

Steady, F. (2006) Women and Collective Action in Africa, New York: Palgrave, Macmillan

Women Solidarity Support Group (2010a) Concept Note Dialogue Forum International Women's Day 2010, Freetown: Women Solidarity Support Group

Women Solidarity Support Group (2010b) Dialogue Forum Final Report, Freetown: Women Solidarity Support Group 